\title{
INDUCTION PROGRAMME: AN ESSENTIAL INGREDIENT FOR STAFF DEVELOPMENT AND QUALITY TEACHER OUTPUT IN BASIC EDUCATION IN NIGERIA
}

\section{ABUBAKAR NDAYELECHI, PhD}

\begin{abstract}
This paper identified the challenges of teachers and that of teaching profession they include: inadequate training, poor condition of service and lack of professionalism. It also looked at induction programme for the beginning teachers, with particular reference to mentoring as a very important model for making quality teachers. The paper made some recommendations, these include: research and experimentation based institutions also serving as centres of innovations, Colleges of Education to be in close ties with societies, revival of Teachers Colleges, in-services training, improvement on criteria for recruitment into training colleges, thorough training in academic subjects and need for continuous assessment of the teacher-trainee and teachers on the job. These recommendations will hopefully bring about the much needed quality teachers if put into use or implemented.
\end{abstract}

\section{Introduction}

Teacher education continues to be the key to educational development here in Nigeria as elsewhere, for without an adequately trained teaching cadre Nigeria cannot hope to expand her educational facilities. As observed by Baike (2002), critics of the present system of teacher education at both the Colleges of Education and in the faculties of education cast some doubt on the quality of teachers being produced by the system. The questions centre around whether the teachers do receive adequate grounding in academic subjects as to make them teach the subject competently. Some critics also argue that all that is required is for teachers to know their teaching subjects very well and that the need for pedagogy is not necessary.

Apart from training, the condition under which Nigerian teachers work could be described as "economic frustration". The attrition rate of teachers is rather high and this is related more to economic factors. Many people take teaching career as a step towards another goal. One immediate effect of this is the low level of commitment to teaching. Commitment requires concentration of efforts, some measure of self-sacrifice and emotional involvement in whatever one does; the teaching profession requires nothing less.

It is also said that the entry qualification into training colleges are lower than those accepted in other disciplines. The fact however remains that the academic respectability of teachers must be enhanced if their role in the community and national development is to be worthwhile and accorded the respect it deserve. This paper considers induction programme for the beginning teachers as well as other teachers a significant issue that needs focused attention, in addition to other considerations out there, that are capable of turning the table for the best. 
Griffin and Hukill (2003) defined induction as the time it takes for a beginning teacher to make the transition from student teacher to teacher. Induction has the potential for incorporating professional learning opportunities that would involve peers, experienced teachers and administrators to act as supervisors, curriculum resource consultants, or mentors.

The process of induction is seen as a time to extend and enrich the teacher's experiential and knowledge base for successive years. This training programme is undertaken in other professions. Law, medicine, accounting and the military, for example, ensure that knowledge and skill acquisition continues as ongoing expectations of professional development within their respective professions, so induction is not a new concept.

\section{Essential Conditions for Staff Development}

Effective induction programmes require many of the same essential conditions as do effective staff development programmes. For example, all professional development activities undertaken by beginning teachers must be relevant and challenging. Furthermore, these activities must also manifest productive and enriched professional experiences for other teachers in the school so as to complement the overall staff development programme. Hence, beginning teachers entering a school that exemplifies source good induction and staff development practices would observe the following situations.

First, well organized induction programme that will be characterized by experienced and beginning teachers participating in the planning, problem solving, decision making and implementing of the induction activities. All teachers would be encouraged to assume control of the induction programme. This would necessitate that the context of the programme be geared to enrich professional experiences as well as to complement instructional practice. Such a setting would enable the whole staff development programme to establish an open climate for decision making and to develop a more responsive communication among all teachers. Working in such a positive staff development environment would give beginning teachers the opportumity more easily to confront instructional or procedural problems and in turn build trust and improved understanding with the experienced teachers.

Second, it is a professional development programme. Induction activities for beginning and experienced teachers should be incorporated into an encompassing professional development plan. This scenario ensures that provisions for professional growth are in - place at various stages of the beginning teacher's career cycle. In this way, there would be recognition of each teacher's individual needs dependent on the specific phase of their professional career i.e. induction, beginning years, five-ten years and so on.

Third, Joyce and Showers, (2004), believe that induction programming should utilize many school-focused activities using various instructional and workshop formats. For example, demonstration, modeling, feedback, and coaching would be inherent in the induction programmes on a regular basis. These school-focused activities would not only ensure greater learning by the beginning teacher but would also enhance long term professional development. Instead of engaging in the one shot pro-d fix, experienced as well as beginning teacher would be encouraged to develop activities that would promote teacher discussion and reflection, i.e. peer supervision, curriculum team planning and so 
on. All these forms of school-focused professional development activities would allow the beginning teacher to enter an instructionally active and supportive professional environment.

Fourth, existence of a supervisory programme with the full support and understanding of all teachers is necessary. Teachers can be supervised in a variety of ways such as: clinical supervision; cooperative or collegial peer supervision; self-directed analysis; administrative monitoring among others. Each approach may provide an avenue for enhancing the communication and supervisory experiences of both beginning and experienced teachers.

Fifth, such factors as access to instructional materials, availability of agents to facilitate change, legislative support evidenced by adequate funding, and professionally acceptable assessment procedures must all be inherent in the induction programme.

Examples of adoption factors that would facilitate induction include:

- introduction of federal and/or state certification regulations and assessment criteria for induction programmes;

- evidence of collaborative planning and implementing activities on the part of teacher education institutions;

- recognition by the profession of the inductee status of beginning teachers and endorsement of assessment procedures;

- use of formative developmental supervision practices;

availability of orientation and instructional resource materials.

\section{The Beginning Teacher's Induction Experiences}

Irrespective of the availability of induction programme in the school, the beginning teacher's entrance into the profession is a most complex and fragile experience. An understanding by teacher educators and experienced teachers of the beginning teacher's initiation into the school and classroom setting is important when establishing induction or staff development programmes.

It should be remembered that the most traumatic transition that teachers make during their professional career begins when they accept their first teaching assignment. Not only do beginning teachers for the first time embrace the contractual, legal and ethical obligations of becoming a professional, but also they encounter the sole responsibility of instructional planning, lesson implementation, pupil assessment and a myriad of other teaching duties.

It is a personally and professionally challenging time for the new professional. For example, each new teacher becomes immersed in the unique educational environment of the school; the social, professional and sometimes political ethos of the staff's interactions exert a powerful influence upon the introductory experiences of the new teacher. In fact, the socialization process of beginning teachers greatly contributes to the reconciliation between the idealism of their professional beliefs and the pragmatic realities of the school as a workplace. According to Zeichner (2003) the socialization process for beginning teachers can be a process of conformity, an adherence to the conventional wisdom and observed practices of the experienced teachers around them. 
For some teachers this is a valued measure of professional acceptance. For others it becomes an overwhelming denial of professional autonomy.

Consequently, support from experienced staff members and the principal must be given to the beginning teacher's unique instructional style, emerging curricular orientation, and initial professional development activities. These considerations are all invaluable factors in the positive maturation of the beginning teacher.

The instructional challenges that the beginning teacher may overcome, or succumb to, during the induction year, according to Haigh and Katterns (2004) are not necessarily directly related to the quality of the preparatory experiences acquired during pre-service. Instructional practice is, instead, incrementally learned through experience that begins in pre-service and continues throughout the induction years. For example, behavior change that leads to professional growth may be reflected in self-evaluative practice and supportive interaction with experienced colleagues and supervisors. Furthermore, the beginning teacher learns by individual and contextual learning experiences rather than by simply implementing a pre-determined curriculum.

According to Hoyles (1996) a teacher's commitment to a systematic study of his or her teaching, accompanied by the confidence to discuss this analysis with other experienced or beginning teachers, will manifest a very powerful professional development experience. Hence, when the beginning teacher's professional experiences are enriched and supported by experienced teachers, many of the problems facing them during the transitory stages of their first years of teaching will be lessened.

Mentoring is an example of an induction practice which will enhance staff development, assuming that conditions for implementing an induction programme are present, particularly the involvement of supportive, experienced teachers and assuming also that the beginning teachers are formally encouraged to take part in the progranme.

\section{Mentoring as an Induction Practice}

Throughout each development stage of the induction experience beginning teachers need their instructional and curriculum innovations to take place under relatively safe conditions. This positive atmosphere will normally result when new teachers receive collegial and judicious support from their more senior colleagues, principals and supervisors in the school.

-According to Gray and Gray, (2005); mentioning means the experienced teacher assisting the beginning teacher gradually to gain competency, confidence, realistic values, experience, self-evaluative skills and curricular knowledge. Interaction between the mentor and beginning teacher may comprise modelling, supervision, coaching, discussion and curriculum collaboration. Eventually as the beginning teacher gains more confidence and competence the mentor minimizes his instructional leadership. The beginning teacher demonstrates acquired skills and knowledge by becoming self-directing, self-evaluating, and eventually responsible for the development of his own professional development program. During this period as the beginning teacher learns and grows, so does the mentor. Five ways that mentors may benefit professionally when working with beginning teachers within an induction staff development mode, according to Gray and Gray (1985) include: 
1) Modelling Different Instructional Methodologies to assist new teachers to expand their repertoire of skills. The mentor is given the chance to present teaching ideas to the beginning teacher. He might choose to model questioning techniques or to demonstrate cueing and reinforcing pupil behavior. Not only would the beginning teacher benefit from observing the experienced teacher in action but also the mentor would receive constructive feedback through the post lesson discussion with the beginning teacher.

2) Providing Regular Observation and Feedback: Teachers engaged in the facilitative and coding role within the supervision cycle also benefit by analyzing their own instructional practice. Too often experienced teachers are isolated from a collegial environment of peer supervision.

3) Working Jointly on the Introduction of New Curriculum Materials for both the New Teacher and Mentor's Classroom: Whatever the curriculum focus, the unique instructional and curricular expertise that both the mentor and beginning teacher may bring to this collegial relationship will result in an expanded resource of ideas for both teachers. For example, an integrated unit of art, music, and physical education focusing on the theme of rhythm might be initiated by both teachers. The mentor's experience and curricular knowledge in art and music might complement the beginning teacher's interest in physical education.

4) Classroom Research: Manageable research that is action-based can focus on instructional issues that arise within both the beginning teacher's and mentor's efforts to improve their teaching. Both could adopt the participant-observer methodology through a case study approach. As Hopkins (2002) posits: doing research in one's own classroom authenticates one's professional craft as well as encourages 'a critical, reflective and self-conscious approach to teaching'.

5) Resource and Consultative Role specifically becoming an Educational Facilitator for other Colleagues. For example, the mentor is responsible for finding and locating resources that would be suitable for the pupils in the beginning teacher's class, i.e. special needs or enriched programmes. Naturally, these resources also become a resource for the mentor. The mentor in essence assumes an important consultative role within the school. Also, the mentor may provide leadership in discussing school regulations, professional expectations of local associations, and ideas for parent conferences. According to Wideen and Andrew (2009) experienced teachers are in need of improving the general knowledge of their professional domain as much as neophyte teachers.

While facilitating these professional activities the mentor may wish to develop an action plan for her own professional development and, further communicate the dimensions of this plan to encourage other colleagues in adopting a beneficial professional practice.

As one can imagine, mentoring process is not easily attainable unless certain factors pertain. For example, the mentor needs to be an exemplary teacher; not necessarily a master teacher in all curriculum areas, but a teacher who understands curriculum and instructional process and concepts. The mentor should also share a compatible philosophical teaching orientation. A good example of the importance of this compatability is the curricular collaboration the mentor and beginning teacher may share when implementing a new curriculum. As well, the mentor must demonstrate positive and empathic interpersonal skills. 


\section{Conclusion}

Teaching takes place within an intellectual context, and requires a mastery of the subject Teaching takes place within an intellectual context, and requires a mathe pech and learn.
matter and an understanding of the peculiarities of human beings who teach and only emerges as a good teacher by getting into a classroom, contending with reality and getting immediate feedback from someone more skillful than he is. This explains why new generation of teachers or the beginning teachers, need some focused attention, especially in an induction programme, to make them become better teachers with better out-put and the trainers, (the experienced teachers too), get more experience through training or mentoring others.

Adoption of a mentoring programme does greatly enhance the induction experiences of the beginning teacher. Hopefully, this cooperative venturing or professional partnership among teachers will promote the value of continuing education programmes, particularly, since teacher education reform needs workable staff development models that are cost effective, incorporates an accountable developmental supervisory process, and promotes self-evaluation and self-direction among teachers. Teachers should be developed to become largely self-directing in their ability to manage their own professional investigations and learning. Hence, induction can become an effective staff development model.

\section{Recommendations}

The proper preparation of teachers who are to operate at a new professional level will require a new definition of institutions for teacher training. The institutions must be deeply involved in research and experimentation and be themselves centres of innovations. They must be prepared to disseminate the tested results of research and to encourage their practical application.

Again, our training colleges should be in close ties with the society, making sure that their work is relevant. However they choose to fill their role, teacher training colleges must be an aggressive force for change in education, not a reflection of the status quo. The roles of the teacher in this category come primarily from the social function of education. Each culture creates different characterization of teacher.

Revival of Teachers Colleges: The scrapped Teachers' Training Colleges should be revived nationwide and National Teaches Institute be reinvigorated and empowered. The College of Education need better feeders. A teacher becomes more competent as a teacher if he has early training from the Teachers' Training College. Those who have had such training among even the university professors can be thought to be born teachers through their approaches. The learners usually enjoy their lectures better. Moreso, since governments are still incapable of employing and filling the primary schools, let alone the secondary schools, with NCE teachers, the Grade II teachers can be used at the primary schools or better still at the nursery instead of "filling the gap" with every Tom, Dick and Jerry. 

Also, Colleges of Education must break through the cordon that has isolated them from
the realities of the communities in which they operate. Teacher-training conducted in
substantial isolation from the realities of the community does not prepars to
administrators to administrators to deal with real chites of the community does not prepare teachers or community resources as well as the school and their world. Our colleges must enlict

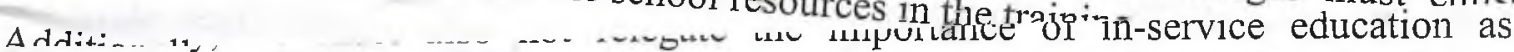
identified in National Curriculum Conference to the background. The role of the Colleges of Education in this all-important activity of in-service requires more critical attention than it usually gets even though it engages a substantial part of the time and talents of educators.

Furthermore, the criteria for recruitment into training Colleges should not be inferior to what obtains in other tertiary institutions; if anything, gaining admission into training Colleges should be more stringent having regard to the role expectation of teachers. Teacher training Colleges have a low standing in the eyes of those who might make the best teachers and this deters them from personal association with the enterprise of education. In order to remove this deterrence, a sustained counter-attack must be launched on the factors which induce good students to avoid teacher training institutions and hence by-pass the teaching profession as a career.

Furthermore, the colleges that are affiliated to faculties of education in universities should create such relationships that the professional and academic standards of the college will be monitored by the Faculty of Education. This will be better achieved if each College is linked with the academic department of the university for the purpose of ensuring that the standards attained in the teaching subjects are not in anyway inferior to what is normally expected at the university. This will help tremendously in improving the quality of teachers in the secondary schools as well as increase the production of teachers at a pace that would gradually eliminate the shortage of trained and qualified teachers in our basic and secondary education levels. This is supported by recommendation No 30 of the 1969 curriculum conference. We should also not lose sight or abandon recommendation No 33 of the 1969 National Curriculum Conference as cited by Fafunwa (1984) as follows:

There is need for a continuous assessment of the teachertrainee and teachers on the job on the effectiveness of their work to challenge pupils to learn more and better. This calls for more and better supervisory systems to ensure the professional competence and growth of the teacher. 


\section{References}

Baike, A. (2002). Recurrent Issues in Nigerian Education. Zaria: Tamaza Publishing Company Ltd.

Fafunwa, A. B. (1984). History of Education in Nigeria. London: George Allen and Unwin.

Gray, W. A. \& Gray, M. M. (2005). 'Synthesis of Research on Mentoring Beginning Teachers'. Educational Leaderships, 43(3): 37-43.

Griffin, G. A. (2005). 'Teacher Induction: Research Issues'. Journal of Teacher Education, XXXVI (1): 42-6.

Griffin, G. A. \& Hukill, H. (2003). First Years of Teaching: WHAT are the Pertinent Issues? Austin, Texas, Research and Development Center for Teacher Education, University of Texas, No. 9051.

Haigh, (2004). Teacher Effectiveness: Problem or Goal for Teachers Education. Journal of Teacher Education. XXXV (5): 23-7.

Hopkins, D. (2002). 'Doing Research in your own Classroom'. Phi Delta Kappan, 64 (4): 274-5.

Hoyles, E. (1996). 'Professionality, Professionalism and Control in Teaching'. London Educational Review, 3 (2): 13-19.

Joyce, B. \& Showers, B. (2004). 'Transfer of Training: The Contribution of Coaching', in Hopkins, D. \& Wideen, M. (Eds). Alternative Perspectives on School Improvement, Philadelphia: Falmer Press.

Wideen, M. F. \& Andrews, I, (2009). Staff Development for School Improvement: A Focus on the Teacher. New York: The Falmer Press.

Zeichner, K. M. (2003). 'Alternative Paradigms of Teacher Education'. Journal of Teacher Education, XXXIV (3): 4. 